\title{
A Study on the Leaf Surfaces Micro- Morphological Characteristics in the Chenopodiaceae
}

\author{
Gamal E.B. El Ghazali ${ }^{1}$, Abdulrhaman A. Al- Soqeer ${ }^{2}$, Wail E. \\ Abdalla $^{1}$
}

${ }^{1}$ Faculty of Science and Arts at Al Rass,

${ }^{2}$ Faculty of Agriculture and Veterinary Medicine, University of Qassim, Saudi Arabia

\begin{abstract}
The aim of the present study is to determine the micro-morphological properties of the leaf surfaces of nine species belonging to the family Chenopodiaceae, using scanning electron microscopy (SEM). Leaf surfaces were noticed to vary considerably with respect to cuticle structural types, stomatal pores position, guard cells cuticular ledges and types of trichomes. Lamellate and lamellate-reticulate cuticular types were recognized. These cuticular folds undergo various patterns, depth and orientation in the various species examined. Sunken, ridged, leveled, raised or depressed stomatal pores were encountered, whereas, the guard cells ledges were poorly or welldeveloped. In Suaeda vermiculata the stomatal pores are sunken in high longitudinal folds rendering the ledges indistinct. Non-glandular unbranched trichomes were detected in Bassia muricata, and collapsed salt bladders were reported in Atriplex leucoclada. The results showed that the micro-morphological characters of the leaf-surfaces examined are considered to be adaptations in response to arid conditions.
\end{abstract}

Keywords: Cuticular Structures, Guard Cells Ledges, Trichomes, Pores Position, Aridity, SEM

\section{Introduction}

Plant surfaces micro- and nano-structures are diverse (Koch et al. 2008), and are evolved in response to their interaction with the environment (Barthlott et al. 2017). These diverse surfaces have led to highly adapted functional structures (Koch \& Barthlott 2009). These functional structures of the plant surfaces provide an effective water transpiration barrier (Riederer \& Muller 2006), provide mechanical stability to the leaves (Bargel et al. 2006), affect trapping efficiency and insect transport (Gorb et al. 2005, Gaume et al. 2002), affect light reflection or absorption of UV radiation (Pfundel et al. 2006), reduce the magnitude of particle adhesion (Koch et al. 2008), affect the spread area of herbicide droplets (Sanyal et al. 2006), act as a barrier against pathogens (Walter 2006), and affect surface wettability (hydrophobic and hydrophilic) leading to self cleaning properties, water repellent surfaces, capillary liquid transport, and drag reduction during moving in water (Koch \& Barthlott 2009, Koch et al. 2008, Neinhuis \& Barthlott 1997).

Aerial plant surfaces (stems, leaves, flowers and fruits) are covered with extra-cellular layer (the cuticle) and contain specialized structures such as trichomes, stomata, ethereal oil cells and hydropotes
(Carpenter 2006). Leaf surfaces perform vital functions to plants and vary enormously in their topography in different taxa (Maiti et al. 2016).

The leaf surfaces of various members of the family Chenopodiaceae were previously examined by scanning electron microscopes (SEM). Various members were examined to study their ecological adaptation in saline habitat (Wang et al. 2015, Shabala 2013, Labidi et al. 2010), or were investigated to examine their taxonomic significance (Klopper \& van Wyk 2001, Sukhorukov 2012, Zhang $\&$ Zhu 1016). The spread area of herbicidal droplets of Chenopodium album was analyzed by Sanyal et al. (2006), whereas the effect of emitted dust particles on the distribution of Atriplex leucoclada was investigated by Oran \& Al Zoubi (2016).

The aim of the present investigation is to study the micro-morphological characteristics of the leaf surfaces of various members of the family Chenopodiaceae from Qassim Region, Saudi Arabia, to determine their structural properties and understand their adaptation to the surrounding environment.

This article is published under the terms of the Creative Commons Attribution License 4.0

Author(s) retain the copyright of this article. Publication rights with Alkhaer Publications.

Published at: http://www.ijsciences.com/pub/issue/2018-12/

DOI: 10.18483/ijSci.1874; Online ISSN: 2305-3925; Print ISSN: 2410-4477 


\section{Material and Methods}

The present investigation was carried out to study the leaf-surfaces of nine species belonging to eight genera of the family Chenopodiaceae collected from Qassim Region (Saudi Arabia). Anabasis setifera Moq., Cornulaca monocantha Del., Seidlitzia rosmarinus Del., Salsola imbricata Forssk. and Suaeda vermiculata Forssk. Ex J.F. Dmel. are succulent species with cylindrical leaves, whereas Atriplex leucoclada Boiss., Bassia muricata (L.) Asch. in Schweinf., Chenopodium ambrosioides L. and $C$. murale L. are non-succulent species.

Leaf-segments of mature fully expanded leaves of approximately $15 \mathrm{~mm}^{2}$ taken halfway between the base and apex of the adaxial surfaces of the lamina were examined. These leaf segments were mounted on aluminum stubs with double-coated carbon conductive tape, with no attempt to remove foreign matters from the surfaces. The segments were then coated with Platinum via (Jeol- 1300) sputter, and examined with (Jeol JSM 5500) scanning electron microscope (SEM). Leaf surfaces were studied with at least three replications for each species and were photographed at X500 and X1000 magnifications.

The terminology used to describe cuticular structures follow Holloway (1982) and Prum et al. (2012).

\section{Results}

Leaf-surfaces of nine species belonging to eight genera of the family Chenopodiaceae from Qassim Region, Saudi Arabia were examined under scanning electron microscope (SEM). These leaf-surfaces showed a considerable variation in cuticle structure types, stomata characteristics and types of trichomes (Figs. 1 and 2).

\section{a. Cuticular structures types:}

The leaf-surfaces of the nine species examined were characterized by the presence of thick cuticular layer. According to differences in their micromorphological characteristics, two types were recognized viz., lamellate and lamellate-reticulate cuticular types. Cuticular folds recognized as high or low, wrinkled or longitudinal (Table 1).

\section{b. Stomata characteristics:}

Stomatal pore position and guard cells cuticular ledges vary considerably among the nine species examined. The stomatal pores were noticed to be sunken, slightly depressed, leveled with the surface, slightly raised or ridged. The guard cells possess conspicuous or prominent wavy broad cuticular ledges (Table 2).

\section{c. Types of trichomes:}

Non-glandular uniseriate recurved short hairs with acuminate apices were detected in Bassia muricata, whereas collapsed salt bladders were reported in Atriplex leucoclada.

Table 1: Cuticular structures of the species examined ( $\mathrm{L}=$ lamellate, $\mathrm{L}-\mathrm{R}=$ lamellate-reticulate).

\begin{tabular}{|c|c|c|c|c|c|}
\hline \multirow[t]{2}{*}{ Taxa } & \multirow[t]{2}{*}{ Type } & \multicolumn{2}{|c|}{ Cuticular folds } & \multirow{2}{*}{$\begin{array}{c}\text { Folds } \\
\text { wrinkled }\end{array}$} & \multirow{2}{*}{$\begin{array}{c}\text { Folds } \\
\text { longitudina }\end{array}$} \\
\hline & & High & Low & & \\
\hline Anabasis setifera & $\mathrm{L}$ & + & & + & \\
\hline Atriplex leucoclada & L-R & & + & + & \\
\hline Bassia muricata & L-R & & + & + & \\
\hline Chenopodium ambrosioides & $\mathrm{L}$ & + & & + & \\
\hline Chenopodium murale & L-R & & + & & + \\
\hline Cornulaca monocantha & L-R & + & & + & \\
\hline Salsola imbricata & $\mathrm{L}$ & + & & + & \\
\hline Seidlitzia rosmarinus & L-R & & + & & + \\
\hline Suaeda vermiculata & $\mathrm{L}$ & + & & & + \\
\hline
\end{tabular}

Table 2: Stomatal characteristics of the species examined $(\mathrm{T}=$ with thin poorly developed irregular borders, $\mathrm{B}=$ with well-developed broad wavy borders).

\begin{tabular}{|c|c|c|c|c|c|c|c|}
\hline \multirow[t]{2}{*}{ Taxa } & \multicolumn{5}{|c|}{ Stomatal pores position } & \multicolumn{2}{|c|}{$\begin{array}{c}\text { Guard } \\
\text { cells } \\
\text { ledges }\end{array}$} \\
\hline & Sunken & Ridged & Leveled & Raised & Depressed & $\mathrm{T}$ & $\mathrm{B}$ \\
\hline Anabasis setifera & & + & & & & + & \\
\hline Atriplex leucoclada & & & & & + & + & \\
\hline Bassia muricata & & & + & & & + & \\
\hline Chenopodium ambrosioides & & & & + & & + & \\
\hline Chenopodium murale & & & + & & & & + \\
\hline
\end{tabular}




\begin{tabular}{|l|c|c|c|c|c|c|c|}
\hline Cornulaca monocantha & & & & & + & + & \\
\hline Salsola imbricata & & & & & + & + & \\
\hline Seidlitzia rosmarinus & & & + & & & & + \\
\hline Suaeda vermiculata & + & & & & & & \\
\hline
\end{tabular}

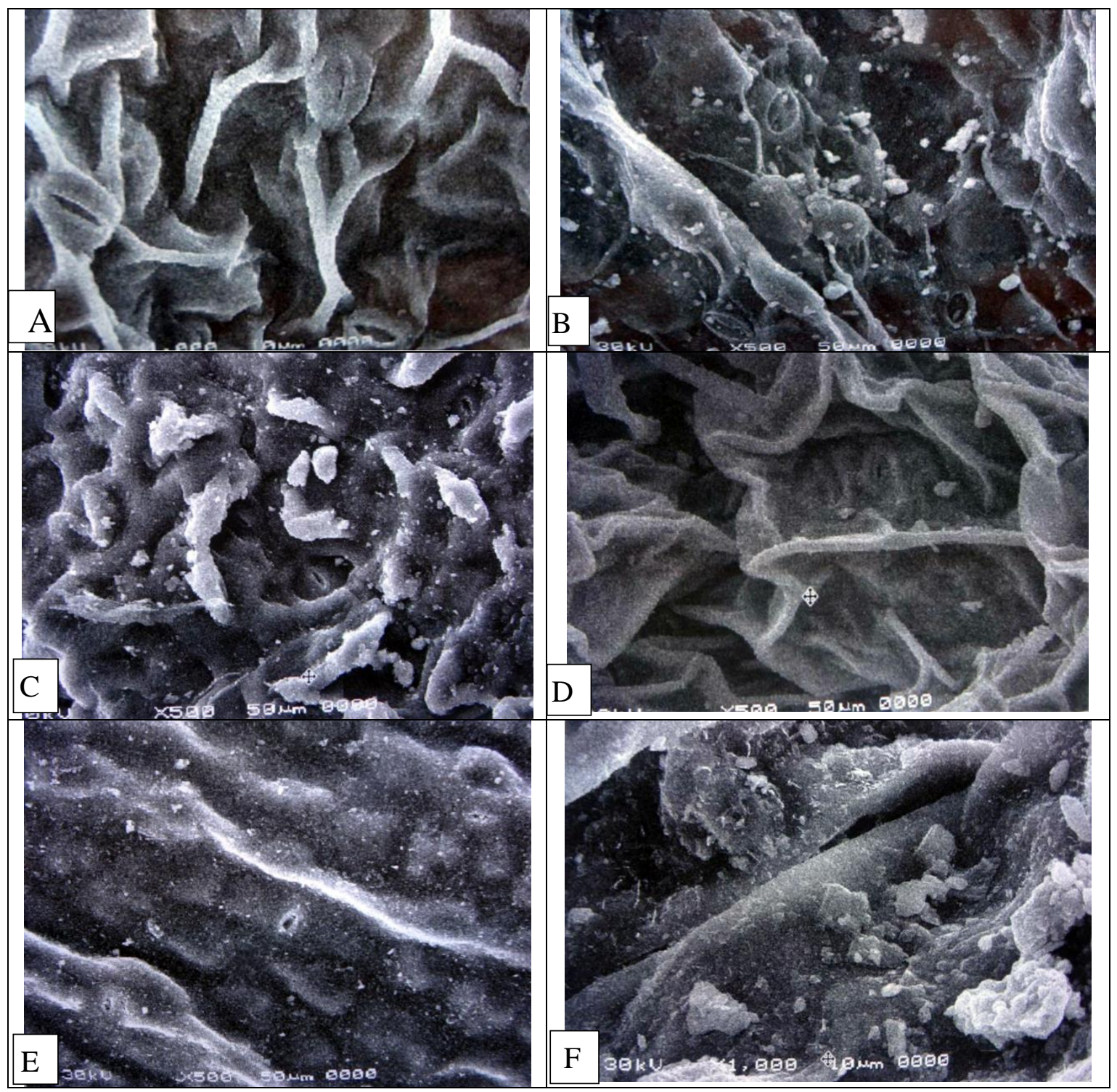

Fig. 1: Scanning electron micrographs of leaf surfaces:

A: Chenopodium ambrosioides X1000, with wrinkled, high cuticular folds and slightly raised stomatal pores.

B: C. murale X500, with lamellate-reticulate cuticular structures and broad well-developedstomatal ledges.

C: Cornulaca monocantha X 500, with high wrinkled cuticular folds and slightly depressed stomatal pores.

D: Salsola imbricata X 500, with high wrinkled cuticular folds and slightly depressed stomatal pores.

E: Seidlitzia rosmarinus X 500, with lamellate-reticulate cuticular structures and stomatal pores leveled with the epidermis.

F: Suaeda vermiculata X 1000, with stomatal pores sunken in high longitudinal folds. 


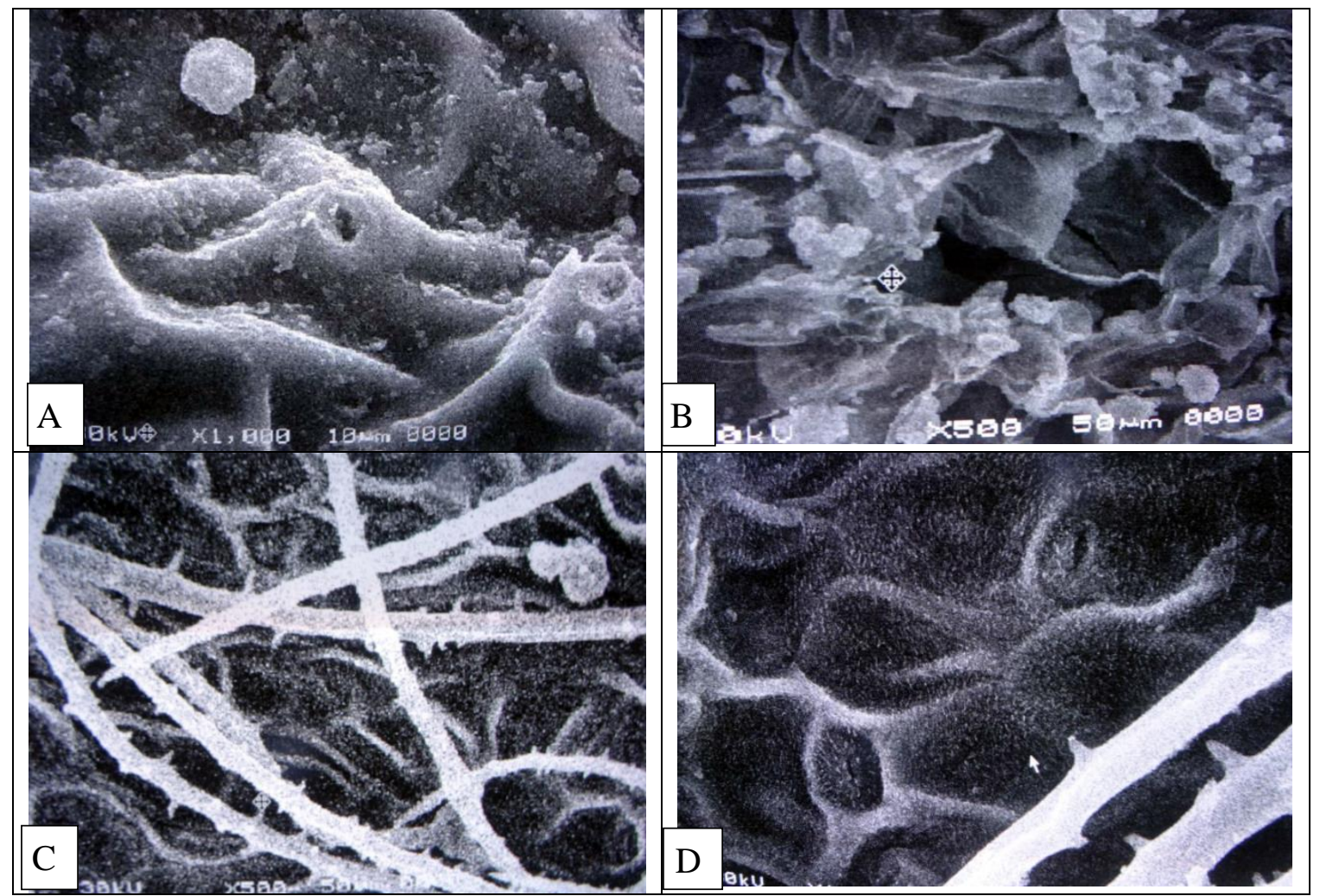

Fig. 2: Scanning electron micrographs of leaf surfaces

A: Anabasis setifera X 1000, with high wrinkled cuticular folds and ridged stomatal pores.

B:Atriplex leucoclada X500, with collapsed salt bladders and depressed stomatal pores.

C-D:Bassia muricata X 500 and X 1000, with uniseriate unbranched trichomes and low wrinkled cuticular folds.

Discussion and Conclusions:

Leaf-surfaces of nine plant species were examined comparatively using (SEM) to evaluate their structural properties and understand their adaptation to the surrounding environment. These species vary considerably with respect to cuticular structure types, position of stomatal pores, presence of cuticular ledges and type of trichomes.

Zarinkamar (2007) in a survey of more than 470 dicotyledonous plant species belonging to 65 families showed that in the Chenopodiaceae, there is minor differences between the adaxial and the abaxial surfaces. This could be attributed to the nearly vertical position of the leaf laminas in the Chenopodiaceae in an attempt to avoid direct sunlight. In the light of the later study, leaf surfaces only on the adaxial surfaces were taken in consideration in the present study.

Stomatal pores within the species examined were not on the same level with the leaf surface. These stomatal pores were encountered to be sunken, slightly depressed, leveled, slightly raised or ridged. This diverse stomatal poral position represent various adaptations to environmental factors affecting the rates of transpiration and photosynthesis (Larcher 2003).

Sunken stomata in the present study were encountered in Suaeda vermiculata. In the latter species, the stomata were not visible and are completely sunken between cuticular folds. Sunken stomata may also be buried in thick cuticle, in cavities formed by raised stomatal rims, in deep pits, between elevations of wax or under hairs (Waldhoff $\&$ Parolin 2010). The presence of sunken stomata were regarded by Jordan et al. (2008) as indication of increasing adaptation to aridity, as distinct xeromorphic feature (Lyshede 1979), and can prevent excessive transpiration losses (Jimenez et al. 2000).

The presence of ridged stomatal pores in Anabasis setifera is another unique leaf surface property within the species examined. These cuticular ridges around the pore opening may radiating (Pearce et al. 2005), wrinkled (van Wyk et al. 1982), curved (Akcin et al. 2012), with buttresses ridges (Waldhoff \& Parolin 2010), with parallel ridges formed by the thickened periclinal walls (Renzaglia, et al. 2017), with striations between or across the ridges (Sun et al. 2010). These cuticular ridges are characteristics of 
plants of arid zones and help to close the pores tightly in response to high vapour pressure deficit (Jenks 2002).

Cuticular ledges of the guard cells (poorly or welldeveloped) were encountered in the nine species examined. Both Chenopodium murale and Seidlitzia rosmarinus were noticed to possess stomatal pores with well-developed broad wavy borders, while the rest of species possess stomatal pores with thin poorly developed irregular borders. The presence of these cuticular ledges highlighted the unique properties of the guard cells. These guard cells are characterized by the presence of proline-rich protein, which lead to cell wall strength and facilitate the interaction with outer cuticle (Hunt et al. 2017). The presence of these cuticular ledges prevent the wide opening of the stomata pores and their rising above the surface of the epidermis (Pautov et al. 2017), and are considered to reduce transpiration (Hunt et al. 2017).

The leaf surfaces of the nine species examined, possess cuticular folds of various patterns, depths and orientations. Longitudinal cuticular folds were noticed in Chenopodium murale, Seidlitzia rosmarinus and Suaeda vermiculata, while the rest of species possess wrinkled cuticular folds. These folds were high in Anabasis setifera, Chenopodium ambrosioides, Cornulaca monocantha, Salsola imbricata and Suaeda vermiculata. On the other hand, the rest of the species possess low cuticular folds. The presence of cuticular folds on leaf surfaces, reduce the effective adhesive devices of insects in carnivorous (Bauer et al. 2018), and non-carnivorous plants (Prum et al. 2012). In addition, these cuticular folds help to increase the wettability of the surfaces of these plants (Bauer et al. 2013) which is highly needed in arid zones such as Qassim Region.

\section{References}

1. Akcin, O.E, Senel, G. and Akcin, Y. (2012). Leaf epidermis morphology of some Onosma (Boraginaceae) species from Turkey. Turkish Journal of Botany, 37-55-64. Doi: 10.3906/bot-1202-33.

2. Bargel, H., Koch, K., Cerman, Z and Neinhuis, C. (2006). Structure-function relationships of the plant cuticle and cuticular waxes - a smart material? Evan Review no. 3. Functional Plant Biology, 33 (10): 893-910. Doi: 10.1071/FP06139.

3. Barthlott, W., Mail, M., Bhushan, B. and Koch, K. (2017). Plant surfaces: structures and functions for biomimetic innovations. Nano- Micro Letters, 9(23): 1-40. Doi: 10.1006/s40820-016-0125-1.

4. Bauer, U., Scharmann, M., Skepper, J. and Federle, W. (2013). Insect aquaplaning on a superhydrophilic hairy surface: how Heliamphora nutans Benth. Pitcher plants capture prey. Proceedings of the Royal Society B: Biological Sciences, 280 (1753): 2012.2569. Doi: 10.1098/rspb.2012.2569.

5. Bauer, U., Jetter, R., and Poppimga, S. (2018). Non-motile traps. In: Ellison, A.M. and Adamec, L. (eds.). Carnivorous plants, physiology, ecology and evolution. Oxford University Press, Oxford. Doi: 10.1093/050/9780198779841.001.0001.

6. Carpenter, K.J. (2006). Specialized structures in the leaf epidermis of basal angiosperms: morphology, distribution and homology. American Journal of Botany, 93(5): 665-681. Doi: 10.3732/ajb.93.5.665.

7. Gaume, L., Gorb, S. and Rowe, N. (2002). Function of epidermal surfaces in the trapping efficiency of Nepenthes alata pitchers. New Phytologist, 156(3): 470-489. http://doi.org/10.1046/j.1469-8137.2002.00530.x.

8. Gorb, E., Haas, K., Henrich, A., Enders, S., Barbakadze, N. and Gorb, S. (2005). Composite structure of the crystalline epicuticular wax layer of the slippery zone in the pitchers of the carnivorous plant Nepenthes alata and its effect on insect attachment. Journal of Experimental Biology, 208: 4651-4662. Doi: $10.1242 /$ jeb.01939.

9. Holloway, P.J. (1982). Structure and histochemistry of plant cuticular membranes: an over view. In: Culter, K.L. and Price, C.E. (eds.), plant cuticle, pp 1-32. Academic press, London. http://www.nal.usda.gov/

10. Hunt, L., Amsbury, S., Baillie, A., Movahedi, M., Mitchell, A., Afsharinafar, M., Swarup, K., Denyer, T., Hobbs, J.K., Swarup, R., Fleming, A.J. and Gray, J.E. (2017). Formation of the stomatal outer cuticular ledge requires a guard cell wall prolinerich protein. Plant Physiology, 174: 689-699. https://doi.org/10.1104/pp.16.01715.

11. Jenks, M.A. (2002). Critical issues with the plant cuticle's function in drought tolerance, In: A.J. Wood (ed.), Biochemical and molecular response of plants to the environment, p. 97-127. Research Signposts, Kerala, India.

12. Jimenez, M.S., Zellnig, G., Stabentheiner, E., Peters, J., Morales, D. and Grill, D. (2000). Structure and ultrastructre of Pinus canariensis needles. Flora, 195(3): 228-235. https://doi.org/10.1016/S0367-2530(17)30975-1.

13. Jordan, G.J., Weston, P.H., Carpenter, R.J., Dillon, R.A. and Brodribb, T.J. (2008). The evolutionary relations of sunken, covered, and encrypted stomata to dry habitats in Proteaceae. American Journal of Botany, 95:521-530.

14. Klopper, R.R. and van Wyk, A.E. (2001). The genus Salsola (Chenopodiaceae) in Southern Africa: Systematic significance of leaf anatomy. South African Journal of Botany, 67(4): 540551.https://doi.org/10.1016/S0254-6299(15)31186-8.

15. Koch, K. and Barthlott, W. (2009). Superhydrophobic and superhydrophilic plant surfaces: an inspiration for biomimetic materials. Philosophical Transactions of the Royal Society A, 367: 1487-1509. Doi: 10.1039/B804854A.

16. Koch, K., Bhushan, B. and Barthlott, W. (2008). Diversity of structure, morphology and wetting of plant surfaces. Soft Matter, 4: 1943-1963.

17. Labidi, N., Ammari, M., Mssedi, D., Benzerti, M., Snoussi, S. and Abdelly, C. (2010). Salt excretion in Suaeda fruticosa. Acta Biol. Hung, 61(3): 299-312.Doi: 10.1556/ABiol.61.2010.3.6.

18. Larcher, W. (2003). Physiological plant ecology, Forth Eds., Cambridge University Press, U.K. https://www.sprnger.com/gp/book/9783540435167.

19. Lyshede, O.B. (1979). Xeromorphic features of three stem assimilant in relation to their ecology. Botanical Journal of the Linnaean Society, 78(2): 85-98.https://doi.org/10.1111/j.10958339.1979.tb02187.x.

20. Maiti, R., Rodriguez, H.G., Balboa, P.C.R., and Kumari, A. (2016). Leaf surface anatomy in some woody plants from northeastern Mexico. Pakistan Journal of Botany, 48(5): 18251831. https://inis.iaea.org/search/search.aspx?orig_q=48014103.

21. Neinhuis, C. and Barthlott, W. (1997). Characterization and distribution of water-repellent, self-cleaning plant surfaces. Annals of Botany, 79(6): 667-677.https://doi.org/10.1006/anbo.1997.0400. 22. Oran, S.A. and Al Zoubi, E. (2016). The impact of the emitted dust from Zarka (Jordan) petroleum refinery on plan biodiversity. International Journal of Current Research in Bioscience and Plant Biology, 3(6): 1-13.Doi: 10.20546/ijcrbp.2016.306.001.

23. Pautov, A., Bauer, S., Ivanova, O., Krylova, E., Sapach, Y. and Gussarova, G. (2017). Role of the outer stomatal ledges in the mechanics of guard cell movements. Tree - Structure and Function, 31(1): 125-135. Doi: 10.1007/s00468-016-1462-x.

24. Pearce,D.W., Millard, S., Bray, D.F. and Rood, S.B. (2005). Stomatal characteristics of riparian poplar species in a semi-arid 
environment. Tree Physiology, 26:211-218. Doi: 10.1093/treephys/26.2.211

25. Pfundel, E.E., Agati, G. and Cerovic, Z.G. (2006). Optical properties of plant surfaces. In: Riederer, M. \& Muller, C. (eds.). Biology of the cuticle. Blackwell Publishing Ltd, Oxford. https://doi.org/10.1002/9781119312994.apr0234.

26. Prum, B., Seidel, R., Bohn, H.F. and Speck, T. (2012). Plant surfaces with cuticular folds are slippery for beetles. Journal of the Royal Society Interface, 9(66): 127-135. Doi: 10.1098/rsif.2011.0202.Epub2011Jun3.

27. Renzaglia, K.S., Villarreal, J.C., Piatkowsk, B.T., Lucas, J.R. and Merced, A. (2017). Hornwort stomata: Architecture and fate shared with 400 million year old fossil plants without leaves. Plant Physiology, 174:788-797.Doi: 10.1104/pp.1700156.

28. Riederer, M. and Muller, C. (2006). Biology of the plant cuticle. Blackwell Publishing Ltd. Doi: 10.1002/9780470988718.fmatter.

29. Sanyal, D, Bhowmik, P.C. and Reddy, K.N. (2006). Leaf characteristics and surfactants affect primisulfuron droplet spread in three broadleaf weeds. Weed Science, 54(1): 16-22. https://doi.org/10.1614/WS-05-019R.1

30. Shabala, S. (2013). Learning from halophytes: physiological basis and strategies to improve abiotic stress tolerance in crops. Annals of Botany, 112(7): 1209-1221. Doi: 10.1093/aoblmct205. 31. Sukhorukov, A.P. (2012). Taxonomic notes on Dysphania and Atriplex (Chenopodiaceae). Willdenowia, 42(2): 169. 180.https://doi.org/10.3372/wi42.42202.
32. Sun, N., He, X., and Zhou, S. (2010). Epidermal morphology of Ligusticum (Apiaceae) from China. Annales Botanici Fennici, 47(4): 261-279. https://doi.org/10.5735/085.047.0403.

33. van Wyk, A.E., Robbertse, P.J. and Kok, P.D.F. (1982). The genus Eugenia L. (Myrtaceae) in southern Africa: the structure and taxonomic value of stomata. Botanical Journal of the Linnaean Society, 84:41-56

34. Waldhoff, D. and Parolin, P. (2010). Morphology and anatomy of leaves. In: Junk, W.J., Piedade, M.T.F., Wittmann, F., Schongart, J. and Parolin, P. (eds.). Amazonian floodplain forests: Ecophysiology, biodiversity and sustainable management (pp. 179202), Springer https://hdl.handle.net/11858/100-001M-0000-000FD518-2.

35. Walter, D.R. (2006). Disguising the leaf surface: the use of leaf coatings for plant disease control. European Journal of plant Pathology, 114(3): 255-260.Doi: 10.1007/s/0658-005-5463-7.

36. Wang, J., Meng, Y., Li, B., Ma, X., Lai, Y., Si, E., Yang, K., Xu, X., Shang, X., Wang, H. and Wang, D. (2015). Physiological and proteomic analysis of salt stress response in the halophyte Halogeton glomeratus. Plant, Cell and Environment, 38:655-669. Doi: $10.1111 /$ pce.12428.

37. Zarinkamar, F. (2007). Stomatal observations in dicotyledons. Pakistan Journal of Biological Sciences, 10(2): 199219. Doi: 10.3923/pjbs.2007.199.219.

38. Zhang, M. and Zhu, G. (1016). Resurrection of the genus Botrydium Spach (Chenopodiaceae), with a description of four new species from China, Peru and Burundi. Plant Diversity, 38(6): 322-329. 